\title{
Pró-existência: uma chave teológica na Cristologia de Joseph Ratzinger
}

\author{
Orientador: Antonio Luiz Catelan Ferreira
}

Doutorando: Everaldo Bon Robert

Área de Concentração: Teologia Sistemático-Pastoral

Linha de Pesquisa: Fé e Cultura

Projeto de Pesquisa: A Teologia de Joseph Ratzinger e o Magistério de Bento XVI

Bento XVI, em sua obra "Jesus de Nazaré: Desde a entrada em Jerusalém até a ressurreição", publicada em 2011, afirmou que a preposição "por" é a palavra-chave para se entender o mistério de Cristo e o significado do seu seguimento, pois introduz na teologia o conceito de pró-existência. A presente tese tem como finalidade estudar como aparece e que lugar ocupa o conceito de pró-existência na obra cristológica de Joseph Ratzinger. Ao desenvolver o presente estudo em quatro capítulos expositivos, o autor se propõe no primeiro capítulo diversas considerações preliminares. No segundo capítulo, a pesquisa expõe a manifestação de Deus como pró-existente no decurso da história. No terceiro, são apresentados os fundamentos da pró-existência: em Jesus, e, a partir de sua revelação, no mistério trinitário. No último capítulo se desenvolve a pró-existência no sacrifício oferecido por Jesus na cruz. O trajeto proposto fundamenta as afirmações de "Jesus de Nazaré". O vocábulo bíblico "por" introduz na Teologia o conceito de pró-existência: a vida de Jesus se caracterizou como uma existência toda voltada "para" o Pai e vivida "para" a salvação da humanidade. Da revelação de Jesus Cristo se é conduzido a conhecer a pró-existência intratrinitária, e, ao mesmo tempo, a considerar a pró-existência do homem enquanto pessoa e cristão. O ápice da entrega de Cristo "para" o Pai e "para" a humanidade se deu no mistério da cruz. Sendo Cristo o constitutivo do ser-cristão, este, ao responder à oferta salvífica feita 
por Cristo na cruz, encontrará a si mesmo e a própria salvação. De modo concreto, o ser humano se descobrirá e será salvo, ao reproduzir em si a atitude fundamental que caracterizou a pessoa e o agir de Jesus: vivendo de forma pró-existente sua entrega confiante e obediente ao Pai, e, ao mesmo tempo, o amor solícito ao próximo.

Palavras-chave: Jesus Cristo. Pró-existência. Joseph Ratzinger. Representação vicário. Cristologia. Soteriologia. 